Multiculturalism and Interculturalism 
From Nasar to Aiisha and Katherine.

From Tariq to Jasmin and Ghizela.

From Ricard to Isabel and Samjana. 


\title{
MULTICULTURALISM AND INTERCULTURALISM
}

\author{
Debating the Dividing Lines
}

$\infty$

Edited by

Nasar Meer, Tariq Modood and Ricard Zapata-Barrero 


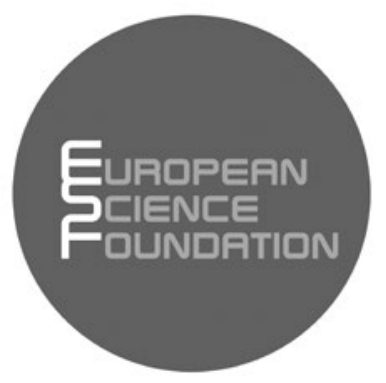

This edited collection includes papers first presented at a two-day European Science Foundation (ESF) exploratory workshop organised by Ricard ZapataBarrero and Tariq Modood, held in Barcelona, 29-30 May 2014. We would like to thank the ESF for their generous funding and support.

Edinburgh University Press is one of the leading university presses in the UK. We publish academic books and journals in our selected subject areas across the humanities and social sciences, combining cutting-edge scholarship with high editorial and production values to produce academic works of lasting importance. For more information visit our website: www.edinburghuniversitypress.com

(C) editorial matter and organisation Nasar Meer, Tariq Modood and Ricard Zapata-Barrero, 2016

(C) the chapters their several authors, 2016

Edinburgh University Press Ltd

The Tun - Holyrood Road

12 (2f) Jackson's Entry

Edinburgh EH8 8PJ

Typeset in 11/14 Sabon by

Servis Filmsetting Ltd, Stockport, Cheshire, and printed and bound in Great Britain by CPI Group (UK) Ltd, Croydon CR0 4YY

A CIP record for this book is available from the British Library

ISBN 9781474407083 (hardback)

ISBN 9781474407090 (paperback)

ISBN 9781474407106 (webready PDF)

ISBN 9781474407113 (epub)

The right of the contributors to be identified as authors of this work has been asserted in accordance with the Copyright, Designs and Patents Act 1988 and the Copyright and Related Rights Regulations 2003 (SI No. 2498). 